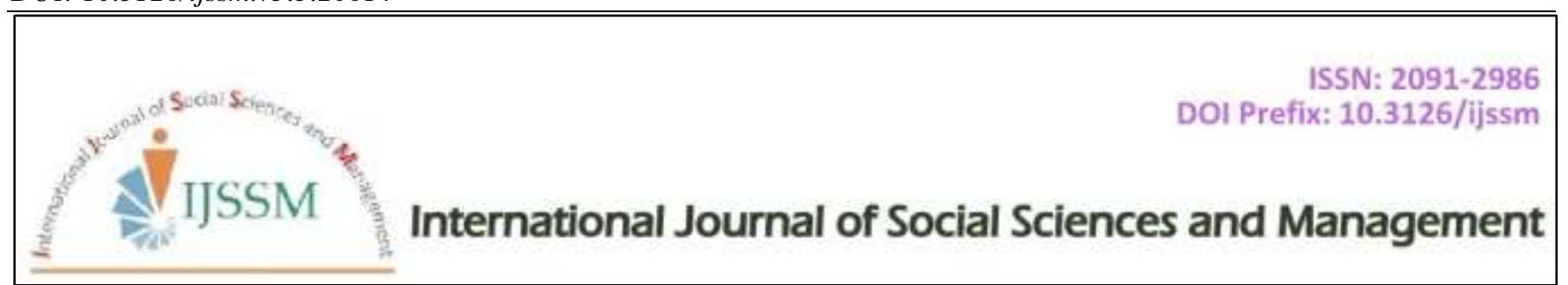

Research Article

\title{
Determination the Level of Knowledge, Attitude, and Practices Regarding Household Waste Disposal among People in Rural Community of Lahore
}

\author{
Ambrin Shahzadi ${ }^{1 *}$, Muhammad Hussain ${ }^{1}$, Muhammad Afzal ${ }^{1}$, Syed Amir Gillani \\ ${ }^{1}$ Lahore School of Nursing, The University of Lahore, Pakistan \\ ${ }^{2}$ Department of Allied Health Sciences, The University of Lahore, Pakistan
}

\begin{abstract}
Introduction: Waste disposal is one of the major environmental problems in all over the world. Improper waste disposal causes breeding and may cause infectious diseases like cholera, small pox, and plague, etc. The knowledge of waste disposal is necessary for health of people's. various study reveal that about $90 \%$ of people disposal of waste in open places and use the method of land filling, so increase the problems for health of public and the environment. The study has been carried out for the current status of waste disposal. Methodology: A cross-sectional study was carried out in rural area and 100 household peoples were the population. The Data collected by pre- tested questionnaire and direct interviewing the people about their routine waste disposal. Results: Majority of respondents (72.0\%) was aware about adverse effects of improper waste removal and $(28.0 \%)$ Respondent was not aware.95.0\% of people have good attitude about waste disposal. Regarding practices most of respondent $(52.0 \%)$ had the poor practices towards waste disposal and $41.0 \%$ had satisfactory practices. Conclusion: The knowledge regarding waste disposal in the most of respondents was found good and in Minimum of respondents having satisfactory knowledge. In spite of good knowledge, the respondents having poor Practices regarding waste disposal due to lack of awareness, unavailability of public dustbins.
\end{abstract}

Keywords: Waste Disposal; Knowledge; Practice; Attitude; Rural area

\section{Introduction}

A Clean environment influences good health and improves quality of human's life. Awareness and education is very necessary about waste disposal for household people (Jatau, 2013). Proper waste disposal is important for protection of environment. Lack of knowledge, irregular and unplanned dumping of waste are the main reasons of improper waste disposal. Poor knowledge about waste disposal is the major Problem for human health. Waste container and dustbins are very important need for dispose of waste. Due to lack of knowledge and insufficient availability of dustbins in homes people are faced many problems (Kiran et al., 2015). Waste consists of all materials that are produced from humans and animals activities and are discarded and

\section{Cite this article as:}

A. shahzadi et al. (2018) Int. J. Soc. Sc. Manage. Vol. 5, Issue-3: 219-224. DOI: 10.3126/ijssm.v5i3.20614

$1 *$ Corresponding author

Ambrin Shahzadi,

Lahore School of Nursing, The University of Lahore, Pakistan

Email: amberi4321@gmail.com

Peer reviewed under authority of IJSSM

(C) 2018 International Journal of Social Sciences and Management

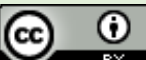

This is an open access article \& it is licensed under a Creative Commons Attribution 4.0 International License (https://creativecommons.org/licenses/by/4.0/) 
useless. Waste disposal mean removing and destroying or storing damaged used or other unwanted materials include packing waste (glass, paper, or plastic), domestic, commercial and agricultural. Disposal including dumping, burial landfill sites (Adogu et al., 2015) People must have knowledge about household waste disposal. Awareness among people about dealing with waste is important. Inadequate and inappropriate knowledge of handling of household waste may have serious health consequences and a significant impact on the environment as well. If people have good knowledge towards household waste disposal they can prevent themselves from infectious diseases and keep their environment is clean (Jatau, 2013). People must have positive attitude towards household waste disposal. The attitude of people towards waste disposal is affected by their level of knowledge. Most of peoples due to lack of knowledge does not used the dustbins. Open defecation poses the serious threat to the health of peoples (Adeyemo, 2013). People with lack of Knowledge regarding household waste disposal have negative attitude towards waste disposal in their homes. They can achieve many health and environmental benefits if people play an important role in waste disposal. They reduce the harmful effects and prevent from many infectious diseases. Inadequate collection and improper disposal of waste facilitates multiplication of pathogens, causing diseases like cholera and diarrhea and provide breeding sites for disease vectors like mosquito (malaria, dengue fever), flies (Diarrhea) and rodent (Adogu et al., 2015).

People must have good practices regarding household waste disposal in their homes. Moreover, Poor waste disposal practices lead to contamination of environment there by increasing the burden of infection and diseases among the peoples. Practices can be improved by providing knowledge regarding household waste disposal. Waste disposal Mass media, television, radio, all can play an important role in improvement of knowledge and practice regarding waste disposal (Thirumarpan et al., 2015).

Globally, 2.6 billion people or 39 percent of the world population do not use proper method for waste disposal. Some 1.1 billion people still disposed of waste in the open places. Improper waste disposal most widely practices in rural areas. So, that people face many health related problems (Shewasinad et al., 2017). Similarly, during survey large number of people that were not disposes household waste and garbage in proper way in rural area. Moreover, there were no proper dustbins for disposed of waste. This study has been conducted in rural area, to assess the knowledge, attitude and practices of people regarding household waste disposal.

\section{Significance of the Study}

This study was enhances the Knowledge, attitude and practices of people regarding household Waste disposal.
The present study is significant in such way that it was assessing the basic knowledge, attitude and practice of community people that deal with waste disposal. The information that was provided, the concern authorities will intervene to bend the existing and potential problem of community and furthermore it will serve as a source of data for future research

\section{Research Purpose}

The purpose of this study is to determine the Knowledge, attitude and practices of people regarding household waste disposal.

\section{Research Question}

Research Question 1: What is the knowledge regarding household waste disposal among people in rural community of Lahore?

Research Question 2: What is the attitude regarding household waste disposal among people in rural community of Lahore?

Research Question 3: What are the practices regarding household waste disposal among people in rural community of Lahore?

\section{Research Objectives}

To assess the Knowledge, Attitude and Practices regarding household waste disposal among people in rural community of Lahore.

\section{Literature Review}

Population is increasing all over the world, especially in developing countries. Similarly, increased amount of household waste is being produced by this growing population. Facilities to manage this waste are limited all over the globe, especially in developing countries, where these are minimal (Sharma et al., 2013). The study was conducted in Pakistan to assess the knowledge and practices shows that $40-65 \%$ of waste in Pakistan is composed of waste material. The composition of waste in 2005 reveals that waste in Lahore contains $21.2 \%$ recyclables, such as plastic, paper, glass and metal. There is no regulation recycling in Pakistan, and the formal sector is not involved in recycling (Batool et al., 2008). The study was conducted in India, to assess the knowledge, attitude and practices towards waste disposal in cities and towns generated an estimated 6 million tones of household waste, and it was about 484 million tones. More than $25 \%$ of the waste is not collected at all $70 \%$ of the Indian cities lack adequate capacity to transport it and there are no sanitary for landfills to dispose of the waste (Kiran et al., 2015). Study was conducted in Somalia to assess the practices of people regarding household waste disposal, most of people $62 \%$ waste the garbage nearby their houses in open places. 
However, many people shows poor attitude towards waste disposal. $32 \%$ people was known about methods of waste disposal but that have lack of dustbins they were not waste the garbage in a proper way (Azuike et al., 2015). Study conducted in Thailand shows that attitude of household people regarding dispose of waste in separate dustbins. (12.2\%) people had moderate intention while $(10.0 \%)$ had low intention to dispose of waste into separate dustbins. Almost (92.2\%) people have good practices to dispose of waste in separate dustbins. Study also shows the practices of people living in Thailand approximately (24.73) people dispose of waste in open places and $50 \%$ people dispose of waste in separate dustbins (Barloa, Lapie, \& de la Cruz).

A study was conducted in Nigeria assess the respondent practice about household waste disposal majority Respondents regarded open dumping as an method (68.9\%), only less than half regarded sanitary land fill (41.3\%) and incineration $(37.4 \%)$ as appropriate methods. Though, infection was reported as a result of inappropriate sanitation practices by a majority of the respondents $(72.7 \%)$, providing a place for criminal hideouts was also reported by as high as $21 \%$ of the respondents (Azuike et al., 2015). Appropriate waste disposal Generally, a majority of the respondents $(60.0 \%)$ had an overall moderate level of knowledge about environmental sanitation with only less than one quarter $(22.9 \%)$ having an overall good level of knowledge (Adogu et al., 2015).

\section{Conceptual Framework}

Dr. Nola J. Pender developed the Health Promotion Model (HPM) that is used universally for research, education, and practice. According to this theory health promotion model focuses on helping people achieve higher levels of wellbeing through health promotion strategies like, educate the people, and change their behavior and practices to promote the health. Through this model enhance the Knowledge, attitude and practices of people. Through this model assess the Knowledge and give awareness about different types of waste. Modify the people attitude and thinking regarding waste disposal and can improved the practices about different method of waste disposal.

\section{Methodology}

Setting: The research has been conducted in homes, a rural area of Lahore, Pakistan.

Research design: A Descriptive cross sectional study has been carried out at rural area of Lahore.

Population: The study population has female and male of rural area age between 15 to 50 years.

Sampling: Data was collected from convenient selected sample of 100 males and females age 15 years to 50 years residents of rural area in Lahore by using a predesigned questionnaire.
Sample size was determined by taking the following assumptions; since there was no previous study in the area, the estimated prevalence rate to be $50 \%$, confidence interval of $95 \%$, margin of error $5 \%$.

Since the study population's number is less than 10,000 and sample size/study population is greater than 0.05 it's calculated by using the following formula with considering adjustment.

Correction formula is used to determine the final sample size. The sample size was 100 of people.

Research Instrument: Data was collected by pre-designed well adopted questionnaire, interview technique on different variables household waste, knowledge, attitude and practices.

Data Gathering Procedure: Convenience sample Technique has been used to collect data on demographic variables, Knowledge, attitude and practice among peoples of rural area.

Analysis of Data: Data analysis was done using SPSS version 21 software. Descriptive statistics has been conducted to obtain frequencies and percentage, proportion tables, Charts, graphs and tables.

Study Timeline: Study has been conducted in 4 month duration from Sep 2017 to Jan 2018.

Ethical Consideration: Ethical approval was takes from Institutional Review board (IRB) University of Lahore. Approval was takes from stake holders of rural area. Informed Written consent was takes from people of rural area.

\section{Results}

\section{Profile of the Respondents}

Table 1 indicates that majority $(43 \%)$ of respondents were 25-34 years of age followed by $(25.0 \%)$ of 15-25years of age, $(23.0 \%)$ of $35-44$ years, and $(9.0 \%)$ were $45-54$ years. majority of respondents were females $(75.0 \%)$ and (25.0) were male. Regarding education maximum respondents (28.0\%) were metric level and minimum $(6.0 \%)$ were post graduate. (38.0\%) were belonged to separate family followed by joint $(61.0 \%)$. Maximum respondents $(53.0 \%)$ were females Housewife.

Table 2 reveals the level of knowledge of respondents, Majority of respondents $(72.0 \%)$ was aware about adverse effects of improper waste removal and $(28.0 \%)$ respondent was not aware. Most community people (83.0\%) were known about more production of waste can harm the environment. Most respondent (40.0\%) were disposed of food category and used the burial method for disposed of waste. 
Table 1: Socio- Demographic Characteristics of Respondents

\begin{tabular}{|c|c|c|c|}
\hline & Variables & Frequency & Percentage \\
\hline \multicolumn{4}{|c|}{ 1. Age of respondent } \\
\hline & $15-25$ year & 25 & 25.0 \\
\hline & $25-34$ & 43 & 43.0 \\
\hline & $35-44$ & 23 & 23.0 \\
\hline & $45-54$ & 9 & 9.0 \\
\hline & Total & 100 & 100.0 \\
\hline \multirow[t]{4}{*}{2.} & Gender & & \\
\hline & Female & 75 & 75.0 \\
\hline & Male & 25 & 25.0 \\
\hline & Total & 100 & 100.0 \\
\hline 3. & Family & & \\
\hline & Joint & 61 & 61.0 \\
\hline & Separate & 38 & 38.0 \\
\hline & Total & 100 & 100.0 \\
\hline \multirow[t]{6}{*}{4.} & Occupation & & \\
\hline & Private job & 25 & 25.0 \\
\hline & Govt job & 21 & 21.0 \\
\hline & House wife & 53 & 53.0 \\
\hline & 5 & 1 & 1.0 \\
\hline & Total & 100 & 100.0 \\
\hline \multirow[t]{8}{*}{5 . } & Education & & \\
\hline & Illiterate & 12 & 12.0 \\
\hline & Primary & 12 & 12.0 \\
\hline & Middle & 23 & 23.0 \\
\hline & Metric & 28 & 28.0 \\
\hline & Under graduate & 19 & 19.0 \\
\hline & Post graduate & 6 & 6.0 \\
\hline & Total & 100 & 100.0 \\
\hline
\end{tabular}

Table 3 Ravels that the Attitude of respondent, Most of community people $(50.0 \%)$ has no idea of waste disposal. $(84.0 \%)$ people were thinking that proper waste disposal is important Mostly respondent $(95.0 \%)$ felt that streets should be clean. But they were not play an important role in household waste disposal.

Table 2: Respondents' Knowledge on Waste Disposal

\begin{tabular}{lcc}
\hline Variables & Frequency & Percen \\
\hline 1 .Improper waste disposal has adverse effect on environmen \\
Wrong & 28 & 28.0 \\
Right & 72 & 72.0 \\
Total & 100 & 100.0
\end{tabular}

2. Waste disposal on open Places can have harmful Effect on human health

\begin{tabular}{lcc} 
Wrong & 17 & 17.0 \\
Right & 83 & 83.0 \\
Total & 100 & 100.0 \\
3. Method of household Waste disposal & \\
Deep burial & 42 & 42.0 \\
Burning, incarnation & 35 & 35.0 \\
Sanitary landfill & 23 & 23.0 \\
Total & 100 & 100.0 \\
\hline
\end{tabular}

Table 3: Respondent Attitude on Waste Disposal

\begin{tabular}{lll}
\hline Variables & Frequency & Percentage
\end{tabular}

1. Do you have an idea of waste disposal?

$\begin{array}{llc}\text { Yes } & 49 & 49.0 \\ \text { No } & 50 & 50.0 \\ 3 & 1 & 1.0 \\ \text { Total } & 100 & 100.0\end{array}$

2. Do you think that proper waste disposal is Important?

$\begin{array}{lll}\text { Yes } & 84 & 84.0\end{array}$

$\begin{array}{lll} & \text { No } & 16\end{array}$

$\begin{array}{lll}\text { Total } & 100 & 100.0\end{array}$

3. Do you feel streets should be clean and free of waste?

\begin{tabular}{lrr} 
Yes & 95 & 95.0 \\
No & 5 & 5.0 \\
Total & 100 & 100.0 \\
\hline
\end{tabular}

Table 4 reveals the level of practice of respondents. Majority of respondents i.e. (39.0\%) reported that they generate 3 bags of garbage per week. Most of them $(58.0 \%)$ responded they were not using bins for waste collection or disposal .Only $(41.0 \%)$ of respondent were using bins for 
waste collection. Majority of respondents (44.0\%) reported that there were not available bins for waste collection. Majority of respondent (42.0\%) were using method of waste disposal thrown on open places. Only $24.0 \%$ people were using the burning method for disposed of waste

Table 4: Respondents Practices on Waste Disposal

Variables $\quad$ Frequency Percentage

$\begin{array}{lll}\begin{array}{l}\text { 1. Garbage generate per } \\ \text { week }\end{array} & \\ 1 \text { bag } & 4 & 4.0 \\ 2 \text { bags } & 22 & 22.0 \\ 3 \text { bags } & 39 & 39.0 \\ \text { More than 4 bags } & 35 & 5.0 \\ \text { Total } & 100 & 100.0\end{array}$

2. Different bins used for waste disposal

$\begin{array}{ccc}\text { Yes } & 41 & 41.0 \\ \text { No } & 58 & 58.0 \\ \text { Total } & 100 & 100.0\end{array}$

3. Number of bins for waste disposal

One 28

Two

No used 44

Total 100

100.0

\section{Waste disposal method}

$\begin{array}{lcc}\text { Decomposed } & 34 & 34.0 \\ \text { Burning } & 24 & 24.0 \\ \text { Thrown on open places } & 42 & 42.0 \\ \text { Total } & 100 & 100.0\end{array}$

\section{Discussion}

The study was done in rural area of Lahore, in our study indicates that majority (43\%) of respondents was 25-34 years of age, and minority ( $9.0 \%$ ) was $45-54$ years. Majority of respondents were females $(75.0 \%)$ and (25.0) were male. $(38.0 \%)$ were belonged to separate family and maximum
$(61.0 \%)$ belongs to joint family. Maximum respondents $(53.0 \%)$ were female's homemaker. In our study regarding education maximum respondents $(28.0 \%)$ were metric level and minimum $(6.0 \%)$ were postgraduates and (12.0\%) were illiterate.

In a similar study done in Kumar Bangalore it was found that $38.3 \%$ had studied up to secondary school $28.0 \%$ had studied up to primary school and $4.0 \%$ were illiterate. In the present study to assess the knowledge, Attitude and practices of community people regarding waste disposal. Majority of respondents $(72.0 \%)$ was aware about adverse effects of improper waste removal and $(28.0 \%)$ respondent was not aware. Study was conducted in South Africa reported that $(80.0 \%)$ of community people have the knowledge about household waste disposal and aware about adverse effects of improper waste disposal. Most community people $(83.0 \%)$ were known about more production of waste can harm the environment. Most respondent $(40.0 \%)$ were disposed of food category and used the burial method for disposed of waste (Adogu et al, 2015). In our study Attitude of most community people $(50.0 \%)$ have no idea of waste disposal. (84.0\%) people were thinking that proper waste disposal is important. Most respondent $(95.0 \%)$ felt that streets should be clean. Most respondent $(71.0 \%)$ were know that improper waste disposal can affect the human's life. But they were not play an important role in household waste disposal.

The study was conducted in Malaysia showed that students $65.9 \%$ have negative attitude towards household waste disposal. In present study practices of community peoples Majority of respondents i.e. (39.0\%) reported that they generate 3 bags of garbage per week .Most of them (58.0\%) responded they were not using bins for waste collection or disposal. Majority of respondents $(44.0 \%)$ reported that there were not available bins for waste collection. Majority of respondent (42.0\%) were using method of waste disposal thrown on open places. Study conducted in Thailand shows that $(71.8 \%)$ people dispose of waste in separate dustbins. (12.2\%) people had moderate intention while (10.0\%) had low intention to dispose of waste into separate dustbins. Almost (92.2\%) people have good practices to dispose of waste in separate dustbins. Study also shows the practices of people living in Thailand approximately (24.73) people dispose of waste in open places and $50 \%$ people dispose of waste in separate dustbins (Moshoette \& Oladele, 2013).

In our study majority of respondents $(44.0 \%)$ reported that there were not available bins for waste collection. Majority of respondent $(42.0 \%)$ were using method of waste disposal thrown on open places. Only $24.0 \%$ people were using the burning method for disposed of waste. A study was done in india to observe the practices regarding waste disposal, shows that $32 \%$ burn the garbage nearby their homes and $27 \%$ waste the garbage in open places. This study shows 
that people have knowledge but lack of resources they were not used the best practices regarding waste disposal (Azuike et al., 2015).

\section{Conclusion}

Level of knowledge regarding waste disposal among the people of rural area was found good. Majority of respondents were aware about the hazardous material and harmful effect of improper waste disposal. The Attitude of community people was found good. The practices of rural people regarding waste disposal was found substantially poor. Despite of having good knowledge the respondents were performing poor practices. Maximum respondents throw waste in open places

\section{Acknowledgement}

My sincere appreciation, thanks and respect provided to HOD of Lahore School of Nursing (LSN).M. Hussain for his valuable and inspiring guidance as evaluator especially thanks to my preceptor Muhammad Hussain for his Continue support and encouragement in the research project. Also thanks to all people of rural area for facilitating data collection and being kind to participate. Also thanks to all those who supported encouraged or facilitated me during my study process.

\section{Limitation}

This study found many limitations:

$>$ Time duration was too short.

$>$ This study was focus only on rural community.

$>$ Data collection was faced lot of issues.

$>$ The respondent of the study have very careless attitude regarding filling questionnaire.

\section{References}

Adeyemo F and Gboyesola G (2013) Knowledge, Attitude and Practices on Waste Management of People Livin in the University Area of Ogbomso, Nigerian. International Journal of Environment Ecology, Family and Urban Studies 3: 51-56.

Adogu P, Uwakwe, K, Egenti N, Okwuoha A and Nkwocha I (2015) Assessment of waste management practices among residents of Owerri Municipal Imo State
Nigeria. Journal of Environmental Protection 6(05): 446.

Azuike E, Nwabueze S, Onyemachi P, Egenti B, Okafor K, Aniemena R and Nwodo J (2015) Household Waste Management; Voices of Residents of Anaocha Local Government Area of Anambra State, Nigeria. Journal of Environmental Protection 6(12): 1394.

Bala, I Knowledge and Practices Regarding Solid Waste Disposal among Rural Community of Muchhali Panchayat, District Una, Himachal Pradesh, India Hindu, 155: 9699

Barloa EP, Lapie LP and de la Cruz CPP Knowledge, Attitudes, and Practices on Solid Waste Management among Undergraduate Students in a Philippine State University

Batool SA, Chaudhry N and Majeed K (2008) Economic potential of recycling business in Lahore. Pakistan Waste management 28(2): 294-298

Group KBS, Dioulasso B, Faso B, Meda N, Fao P, KyZerbo, Ouedraogo PE (2012) Maternal HIV-1 disease progression 18-24

Jatau AA (2013) Knowledge, attitudes and practices associated with waste management in Jos South Metropolis. Plateau State Mediterranean Journal of Social Sciences 4(5): 119.

Kiran K, Kini S, Santhosh N, Kiran NU (2015) KAP study of solid waste disposal of households in Kuttar \& Manjanadi Panchayath covered under gramaskhema programme of KS Hegde Medical Academy. Nitte University Journal of Health Science. 5(3).

Merriam-Webster (2004) Merriam-Webster's collegiate dictionary: Merriam-Webster.

Momodu NS, Dimuna KO \& Dimuna, JE (2011) Mitigating the impact of solid wastesin urban centres in Nigeria. Journal of Human Ecology 34(2): 125-133.

Performance evaluation of reactive routing protocols in MANET networks using GS based voice traffic applications. Optik-International Journal for Light and Electron Optics 124(15). 